\title{
Health risks from radiofrequency radiation, including 5G, should be assessed by experts with no conflicts of interest
}

\author{
LENNART HARDELL and MICHAEL CARLBERG \\ The Environment and Cancer Research Foundation, SE-702 17 Örebro, Sweden
}

Received April 8, 2020; Accepted June 19, 2020

DOI: $10.3892 / \mathrm{ol} .2020 .11876$

\begin{abstract}
The fifth generation, 5G, of radiofrequency (RF) radiation is about to be implemented globally without investigating the risks to human health and the environment. This has created debate among concerned individuals in numerous countries. In an appeal to the European Union (EU) in September 2017, currently endorsed by $>390$ scientists and medical doctors, a moratorium on $5 \mathrm{G}$ deployment was requested until proper scientific evaluation of potential negative consequences has been conducted. This request has not been acknowledged by the EU. The evaluation of RF radiation health risks from $5 \mathrm{G}$ technology is ignored in a report by a government expert group in Switzerland and a recent publication from The International Commission on Non-Ionizing Radiation Protection. Conflicts of interest and ties to the industry seem to have contributed to the biased reports. The lack of proper unbiased risk evaluation of the $5 \mathrm{G}$ technology places populations at risk. Furthermore, there seems to be a cartel of individuals monopolizing evaluation committees, thus reinforcing the no-risk paradigm. We believe that this activity should qualify as scientific misconduct.
\end{abstract}

\section{Introduction}

Most politicians and other decision-makers using guidelines for exposure to radiofrequency $(\mathrm{RF})$ radiation seem to ignore the risks to human health and the environment. The fact that the International Agency for Research on Cancer (IARC) at

Correspondence to: Dr Lennart Hardell, The Environment and Cancer Research Foundation, Studievägen 35, SE-702 17 Örebro, Sweden

E-mail: lennart.hardell@environmentandcancer.com

Key words: Switzerland, European Union, World Health Organization, International Commission on Non-Ionizing Radiation Protection, Scientific Committee on Emerging and Newly Identified Health Risks, Swedish Radiation Safety Authority, 5G, electromagnetic field, appeals, moratorium, microwave radiation, radiofrequency electromagnetic field, health risks, non-ionizing radiation guidelines, conflicts of interest the World Health Organization (WHO) in May 2011 classified $\mathrm{RF}$ radiation in the frequency range of $30 \mathrm{kHz}$ to $300 \mathrm{GHz}$ to be a 'possible' human carcinogen, Group $2 \mathrm{~B}(1,2)$, is being ignored. This has been recently exemplified in a hearing at the Tallinn Parliament in Estonia (3).

An important factor may be the influence on politicians by individuals and organizations with inborn conflicts of interests (COIs) and their own agenda in supporting the no-risk paradigm $(4,5)$. The International Commission on Non-Ionizing Radiation Protection (ICNIRP) has repeatedly ignored scientific evidence on adverse effects of RF radiation to humans and the environment. Their guidelines for exposure are based solely on the thermal (heating) paradigm and were first published in ICNIRP 1998 (6), updated in ICNIRP 2009 (7) and have now been newly published in ICNIRP 2020 (8), with no change of concept, only relying on thermal effects from RF radiation on humans. The large amount of peer-reviewed science on non-thermal effects has been ignored in all ICNIRP evaluations $(9,10)$. Additionally, ICNIRP has successfully maintained their obsolete guidelines worldwide.

COIs can be detrimental, and it is necessary to be as unbiased as possible when assessing health risks. There are three points that should be emphasized. Firstly, the evidence regarding health risks from environmental factors may not be unambiguous, and therefore informed judgements must be made. Furthermore, there are gaps in knowledge that call for experienced evaluations, and no conclusion can be reached without value judgements. Secondly, paradigms are defended against the evidence and against external assessments by social networks in the scientific community. Thirdly, the stronger the impact of decisions about health risks on economic, military and political interests, the stronger will stakeholders try to influence these decision processes.

Since the IARC evaluation in $2011(1,2)$, the evidence on human cancer risks from RF radiation has been strengthened based on human cancer epidemiology reports (9-11), animal carcinogenicity studies (12-14) and experimental findings on oxidative mechanisms (15) and genotoxicity (16). Therefore, the IARC Category should be upgraded from Group 2B to Group 1, a human carcinogen (17).

The deployment of the fifth generation, $5 \mathrm{G}$, of $\mathrm{RF}$ radiation is a major concern in numerous countries, with groups of citizens trying to implement a moratorium until thorough research 
on adverse effects on human health and the environment has been performed. An appeal for a moratorium, currently signed by $>390$ international scientists and medical doctors, was sent to the European Union (EU) in September 2017 (18), currently with no EU response (19). Several regions have implemented a moratorium on the deployment of $5 \mathrm{G}$ motivated by the lack of studies on health effects, for instance Geneva (20).

In the present article, the current situation in Switzerland is discussed as an example (21). Additionally, the ICNIRP 2020 evaluation is discussed (8).

\section{Evaluation of health risks in Switzerland}

Several Swiss citizens have brought to our attention that Associate Professor Martin Röösli is the chair of two important government expert groups in Switzerland (directeur), despite possible COIs and a history of misrepresentation of science $(22,23)$. These groups are Beratende Expertengruppe NIS (BERENIS; the Swiss advisory expert group on electromagnetic fields and non-ionizing radiation) (24), and the subgroup 3, the MobileCommunications and Radiation Working Group of the Department of the Environment, Transport, Energy and Communications/Eidgenössisches Departement für Umwelt, Verkehr, Energie und Kommunikation, evaluating RF-radiation health risks from $5 \mathrm{G}$ technology $(25,26)$.

The conclusions made in the recent Swiss government $5 \mathrm{G}$ report are biased and can be found here $(27,28)$. This $5 \mathrm{G}$ report concluded that there is an absence of short-term health impacts and an absence or insufficient evidence of long-term effects [see Table 17 (Tableau 17) on page 69 in the French version (27) and Table 17 (Tabelle 17) on page 67 in the German version (28)].

Furthermore, it was reported that there is limited evidence for glioma, neurilemmoma (schwannoma) and co-carcinogenic effects, and insufficient evidence for effects on children from prenatal exposure or from their own mobile phone use. Regarding cognitive effects, fetal development and fertility (sperm quality), the judgement was that the evidence on harmful effects is insufficient. These evaluations were strikingly similar to those of the ICNIRP (see Appendix B in ICNIRP 2020; 8). Other important endpoints, such as effects on blood-brain barrier, cell proliferation, apoptosis (programmed cell death), oxidative stress (reactive oxygen species) and gene and protein expression, were not evaluated.

According to Le Courrier November 19, 2019, Martin Röösli presented the conclusion in an interview in the following way: 'Sur l'aspect sanitaire pur, «le groupe de travail constate que, jusqu'à présent, aucun effet sanitaire n'a été prouvé de manière cohérente en dessous des valeurs limites d'immissions fixées», résume Martin Röösli, professeur d'épidémiologie environnementale à l'Institut tropical et de santé publique suisse' (29). [Regarding the health issue, the working group concludes that, until now, no health effect has been consistently proven below the given exposure limits, summarizes Martin Röösli, professor in environmental epidemiology at the Swiss Tropical and Public Health Institute].

This Swiss evaluation is scientifically inaccurate and is in opposition to the opinion of numerous scientists in this field (18). In addition, 252 electromagnetic field (EMF) scientists from 43 countries, all with published peer-reviewed research on the biologic and health effects of nonionizing electromagnetic fields (RF-EMF) have stated that:

'Numerous recent scientific publications have shown that RF-EMF affects living organisms at levels well below most international and national guidelines. Effects include increased cancer risk, cellular stress, increase in harmful free radicals, genetic damages, structural and functional changes of the reproductive system, learning and memory deficits, neurological disorders, and negative impacts on general wellbeing in humans. Damage goes well beyond the human race, as there is growing evidence of harmful effects to both plant and animal life' (30).

We are concerned that the Swiss $5 \mathrm{G}$ report may be influenced by ties to mobile phone companies (COIs) by one or several members of the evaluating group.

\section{COIs}

Funding from telecom companies is an obvious COI. Martin Röösli has been a member of the board of the telecom funded Swiss Research Foundation for Electricity and Mobile Communication (FSM) organization and he has received funding from the same organization (31-33).

It should be noted that the FSM is a foundation that serves formally as an intermediate between industry and researchers. According to their website, among the five founders of FSM who 'provided the initial capital of the Foundation' four are telecommunications companies: Swisscom, Salt, Sunrise, 3G Mobile (liquidated in 2011). The fifth founder is ETH Zurich (technology and engineering university). There are only two sponsors, Swisscom (telecommunications) and Swissgrid (energy), who 'support the FSM with annual donations that allow for both the management of the Foundation and research funding' (34).

The same situation applies to being a member of ICNIRP (Table I) (35). In 2008, the Ethical Council at Karolinska Institute in Stockholm stated that being a member of ICNIRP is a potential COI. Such membership should always be declared. This verdict was based on activities by Anders Ahlbom in Sweden, at that time a member of ICNIRP, but is a general statement (2008-09-09; Dnr, 3753-2008-609). In summary: 'It is required that all parties clearly declare ties and other circumstances that may influence statements, so that decision makers and the public may be able to make solid conclusions and interpretations. AA [Anders Ahlbom] should thus declare his tie to ICNIRP whenever he makes statements on behalf of authorities and in other circumstances' (translated into English).

COIs with links to industry are of great importance; these links may be direct or indirect funding for research, payment of travel expenses, participation in conferences and meetings, presentation of research, etc. Such circumstances are not always declared as exemplified above. A detailed description was recently presented for ICNIRP members (22).

\section{ICNIRP}

ICNIRP is a non-governmental organization (NGO) based in Germany. Members are selected via an internal process, and the organization lacks transparency and does not represent the 
Table I. Members of the WHO core group and additional experts of the Environmental Health Criteria Document 2014 (54), EU SCENIHR 2015 (52), the SSM 2015-2020 (93) and ICNIRP commission or the Scientific Expert Group 1992-2020 (94).

\begin{tabular}{|c|c|c|c|c|}
\hline Members & WHO, 2014 & SCENIHR, 2015 & SSM, 2015-2020 & ICNIRP, 1992-2020 \\
\hline Emilie van Deventer & $\mathrm{X}$ & & $\mathrm{X}$ & $\mathrm{X}^{\mathrm{a}}$ \\
\hline Simon Mann & $X$ & & & $\mathrm{X}$ \\
\hline Maria Feychting & $\mathrm{X}$ & & $(\mathrm{X})^{\mathrm{b}}$ & $\mathrm{X}$ \\
\hline Gunnhild Oftedal & $X$ & & & $\mathrm{X}$ \\
\hline Eric van Rongen & $X$ & & $X$ & $X$ \\
\hline Maria Rosaria Scarfi & $X$ & $\mathrm{X}$ & $\mathrm{X}$ & $\mathrm{X}$ \\
\hline Jukkka Juutilainen & $X$ & & & $\mathrm{X}$ \\
\hline Denis Zmirou & $X$ & & & \\
\hline Theodoros Samaras & & $X$ & & \\
\hline Norbert Leitgeb & & $X$ & & \\
\hline Anssi Auvinen & & $X$ & & $X$ \\
\hline Heidi Danker Hopfe & & $X$ & $X$ & \\
\hline Kjell Hansson Mild & & $\mathrm{X}$ & & \\
\hline Mats Olof Mattsson & & $X$ & & $X$ \\
\hline Hannu Norppa & & $\mathrm{X}$ & & \\
\hline James Rubin & $X$ & $X$ & & \\
\hline Joachim Schüz & & $X$ & & \\
\hline Zenon Sienkiewicz & $X$ & $X$ & & $\mathrm{X}$ \\
\hline Olga Zeni & $X$ & $\mathrm{X}$ & & \\
\hline Anke Huss & & & $\mathrm{X}$ & $\mathrm{X}^{\mathrm{c}}$ \\
\hline Clemens Dasenbrock & & & $X$ & $X$ \\
\hline Lars Klaeboe & & & $X$ & \\
\hline Martin Röösli & $X$ & & $X$ & $\mathrm{X}$ \\
\hline Aslak Harbo Poulsen & & & $\mathrm{X}$ & \\
\hline
\end{tabular}

${ }^{a}$ WHO Observer in the main commission (95); ${ }^{\text {22002-2011; }}$ 2020-2024. The table is based on members of WHO, SCENIHR and SSM during the defined time period(s). No other individuals among those within WHO or SCENIHR were found in the list of SSM participants. A total of 15 additional experts in WHO were not members of SCENIHR, SSM or ICNIRP. SCENIHR, Scientific Committee on Emerging and Newly Identified Health Risks; SSM, Swedish Radiation Safety Authority; WHO, World Health Organization; EU, European Union; ICNIRP, International Commission on Non-Ionizing Radiation Protection.

opinion of the majority of the scientific community involved in research on health effects from RF radiation. Independent international EMF scientists in this research area have declared that: 'In 2009, the ICNIRP released a statement saying that it was reaffirming its 1998 guidelines, as in their opinion, the scientific literature published since that time has provided no evidence of any adverse effects below the basic restrictions and does not necessitate an immediate revision of its guidance on limiting exposure to high frequency electromagnetic fields. ICNIRP continues to the present day to make these assertions, in spite of growing scientific evidence to the contrary. It is our opinion that, because the ICNIRP guidelines do not cover long-term exposure and low-intensity effects, they are insufficient to protect public health' (30).

ICNIRP only acknowledges thermal effects from RF radiation. Therefore, the large body of research on detrimental non-thermal effects is ignored. This was further discussed in a peer-reviewed scientific comment article (3).

In 2018, ICNIRP published 'ICNIRP Note: Critical Evaluation of Two Radiofrequency Electromagnetic Field Animal Carcinogenicity Studies Published in 2018' (36). It is surprising that this note claims that the histopathological evaluation in the US National Toxicology Program (NTP) study on animals exposed to RF radiation was not blinded $(12,13)$. In fact, unfounded critique of the NTP study had already been rebutted (37); however, this seems to have had little or no impact on this ICNIRP note casting doubt on the findings of the animal study: 'This commentary addresses several unfounded criticisms about the design and results of the NTP study that have been promoted to minimize the utility of the experimental data on RFR [radiofrequency radiation] for assessing human health risks. In contrast to those criticisms, an expert peerreview panel recently concluded that the NTP studies were well designed, and that the results demonstrated that both GSM-and CDMA-modulated RFR were carcinogenic to the heart (schwannomas) and brain (gliomas) of male rats' (37).

In contrast to the opinion of the 13 ICNIRP commission members, the IARC advisory group of 29 scientists from 18 countries has recently stated that the cancer bioassay in experimental animals and mechanistic evidence warrants high priority re-evaluation of the RF radiation-induced carcinogenesis (38). 
ICNIRP draft. On July 11, 2018, ICNIRP released a draft on guidelines (39) for limiting exposure to time-varying electric, magnetic and electromagnetic fields $(100 \mathrm{kHz}$ to $300 \mathrm{GHz})$. It was open for public consultations until October 9, 2018. Appendix B was based on assessment of health risks based on a literature survey (39).

Surprisingly, the IARC classification of RF-EMF exposure as Group 2B ('possibly' carcinogenic to humans) from 2011 was concealed in the background material to the new ICNIRP draft on guidelines. Notably, one of the ICNIRP commission members, Martin Röösli (40), was also one of the IARC experts evaluating the scientific RF carcinogenicity in May 2011 (41). He should be well aware of the IARC classification. The IARC classification contradicts the scientific basis for the ICNIRP guidelines, making novel guidelines necessary and providing a basis to halt the rollout of $5 \mathrm{G}$ technology.

Therefore, the ICNIRP provides scientifically inaccurate reviews for various governments. One issue is that only thermal (heating) effects from RF radiation are considered, and all non-thermal effects are dismissed. An analysis from the UK demonstrates these inaccuracies (4), also discussed in another article (5). All members of the ICNIRP commission are responsible for these biased statements that are not based on solid scientific evidence.

ICNIRP release of novel guidelines for $R F$ radiation. On March 11, 2020, ICNIRP published their novel guidelines for exposure to EMFs in the range of $100 \mathrm{kHz}$ to $300 \mathrm{GHz}$, thus including 5G (8). The experimental studies demonstrating a variety of non-thermal biological/health effects $(9,10)$ are not considered, as in their previous guidelines (6,7). Additionally, the ICNIRP increased the reference levels for the general public averaged over $6 \mathrm{~min}$ for $\mathrm{RF}$ frequencies $>2-6 \mathrm{GHz}$ (those that will be used for $5 \mathrm{G}$ in this frequency range), from $10 \mathrm{~W} / \mathrm{m}^{2}$ (Tables 5 and 7 in ref. no. 6) to $40 \mathrm{~W} / \mathrm{m}^{2}$ (Table 6 in ref. no. 8), which paves the way for even higher exposure levels to $5 \mathrm{G}$ than the already extremely high ones.

Background dosimetry is discussed in Appendix A of the ICNIRP 2020 guidelines (8). The discussion on 'Relevant Biophysical Mechanisms' should be criticized. The only mechanism considered by ICNIRP is temperature rise, which may also occur with $5 \mathrm{G}$ exposure, apart from the established non-thermal biological/health effects $(42,43)$. It is well known among experts in the EMF-bioeffects field that the recorded cellular effects, such as DNA damage, protein damage, chromosome damage and reproductive declines, and the vast majority of biological/health effects are not accompanied by any significant temperature rise in tissues (44-47). The ion forced-oscillation mechanism (48) should be referred to as a plausible non-thermal mechanism of irregular gating of electrosensitive ion channels on cell membranes, resulting in disruption of the cell electrochemical balance and initiating free radical release and oxidative stress in the cells, which in turn causes genetic damage $(15,49)$. The irregular gating of ion channels on cell membranes is associated with changes in permeability of the cell membranes, which ICNIRP admits in its summary (8).

Health risks are discussed in Appendix B of the ICNIRP 2020 guidelines (8). Again, only thermal effects are considered, whereas literature on non-thermal health consequences is disregarded $(9,10,50)$. In spite of public consultations on the draft, the final published version on health effects is virtually identical to the draft version, and comments seem to have been neglected (19). In the following section, Appendix B on health effects (8) is discussed.

Appendix B starts with: 'The World Health Organization (WHO) has undertaken an in-depth review of the literature on radiofrequency electromagnetic fields (EMFs) and health, which was released as a Public Consultation Environmental Health Criteria Document in 2014... Further, the Scientific Committee on Emerging and Newly Identified Health Risks (SCENIHR), a European Commission initiative, also produced a report on potential health effects of exposure to electromagnetic fields (SCENIHR 2015), and the Swedish Radiation Safety Authority (SSM) have produced several international reports regarding this issue (SSM 2015, 2016, 2018). Accordingly, the present guidelines have used these literature reviews as the basis for the health risk assessment associated with exposure to radiofrequency EMFs rather than providing another review of the individual studies'.

In the last 11 years since its previous ICNIRP 2009 statement (7), ICNIRP has not managed to conduct a novel evaluation of health effects from RF radiation. However, as shown in Table I, several of the present ICNIRP members are also members of other committees, such as the EU Scientific Committee on Emerging and Newly Identified Health Risks (SCENIHR), the Swedish Radiation Safety Authority (SSM) and the WHO, thus creating a cartel of individuals known to propagate the ICNIRP paradigm on RF radiation $(4,5,22,51)$. In fact, six of the seven expert members of the WHO, including Emelie van Deventer, were also included in ICNIRP $(5,7)$. Therefore, Emilie van Deventer, the team leader of the Radiation Programme at WHO (the International EMF Project), is an observer on the main ICNIRP commission, and SSM seems to be influenced by ICNIRP. Among the current seven external experts (Danker-Hopfe, Dasenbrock, Huss, Harbo Polusen, van Rongen, Röösli and Scarfi), five are also members of ICNIRP, and van Deventer used to be part of SSM.

As discussed elsewhere (5), it is unlikely that a person's evaluation of health risks associated with exposure to RF radiation would differ depending on what group the person belongs to. Therefore, by selecting group members, the final outcome of the evaluation may already be predicted (no-risk paradigm). Additionally, we believe that this may compromise sound scientific code of conduct.

The SCENIHR report from 2015 (52) has been used to legitimate the further expansion of the wireless technology and has been the basis for its deployment in a number of countries. One method, applied in the SCENIHR report, to dismiss cancer risks involves the selective inclusion of studies, excluding studies reporting cancer risks and including some investigations with inferior epidemiological quality. The report has been heavily criticized by researchers with no COI (53): 'In January of 2015, the Scientific Committee on Emerging and Newly Identified Health Risks (SCENIHR) published its final opinion on (P)otential health effects of exposure to electromagnetic fields... SCENIHR has not answered the question it was appointed to investigate. The Committee has answered a 
different question, limiting its conclusions to whether certainty or causal effect is established, instead of possibility of health risks... Overall, SCENIHR has not conducted a scientific review process for judging possible health risks. This results in erroneous and deceptive conclusions by failing to conclude such possible health risks do exist. Evidence that SCENIHR has presented clearly and conclusively demonstrates that EMF health risks are possible, and in some cases are established. The Committee is obligated to draw to the attention of the European Commission that EMF is a new and emerging problem that may pose an actual or potential threat'.

Regarding the SSM, only yearly updates are available and no overall evaluations are made. Therefore, no thorough review is presented. Over the years, the ICNIRP has dominated this committee (Table I). Therefore, it is unlikely that the opinion of the SSM will differ from that of the ICNIRP.

In 2014, the WHO launched a draft of a Monograph on RF fields and health for public comments (54). It should be noted that the WHO issued the following statement: 'This is a draft document for public consultation. Please do not quote or cite'. ICNIRP completely ignored that request and used the aforementioned document. The public consultations on the draft document were dismissed and never published.

In addition to van Deventer, five of the six members (Mann, Feychting, Oftedal, van Rongen, and Scarfi) of the Core Group in charge of the WHO draft were also affiliated with ICNIRP, which constitutes a COI (Table I). Scarfi is a former member of ICNIRP (5). Several individuals and groups sent critical comments to the WHO on the numerous shortcomings in the draft of the Monograph on RF radiation. In general, the WHO never responded to these comments and it is unclear to what extent, if any, they were even considered. Nevertheless, the final version of the WHO 'in-depth review' has never been published. Instead, WHO made a call on October 8, 2019 (Emelie van Deventer), for systematic reviews to analyze and synthesize the available evidence: 'Through this Call, WHO invites eligible teams to indicate their interest in undertaking a systematic review on one (or more) of the following topics: SR1 - Effect of exposure to RF on cancer (human observational studies); SR2 - Effect of exposure to RF on cancer (animal studies); SR3 - Effect of exposure to $R F$ on adverse reproductive outcomes (human observational studies); SR4 - Effect of exposure to RF on adverse reproductive outcomes (animal and in vitro studies); SR5 - Effect of exposure to RF on cognitive impairment (human observational studies; SR6 - Effect of exposure to $R F$ on cognitive impairment (human experimental studies); SR7 - Effect of exposure to RF on symptoms (human observational studies); SR8 - Effect of exposure to RF on symptoms (human experimental studies; SR9 - Effect of exposure to RF on biomarkers of oxidative stress; SR10 - Effect of exposure to heat from any source and pain, burns, cataract and heatrelated illness'.

The authors of the present article were part of a team that applied to review SR1- human cancer. On December 20, 2019, the following reply was received from the WHO Radiation Programme: 'After careful review, we have decided to choose another team for this systematic review'.

Transparency is of importance for the whole process. Therefore, a query was sent to the WHO requesting informa- tion regarding the following points: 'Who did the evaluation of the groups that answered the call? What criteria were applied? How many groups had submitted and who were these? Which groups were finally chosen for the different packages?'. In spite of sending the request four times, January 2, January 3, April 7 and April 30, 2020, there has been no reply from WHO. This appears to be a secret process behind closed doors. These circumstances have also been reported in Microwave News (55).

It is important to comment on the current ICNIRP evaluation. Notably, on February 27, 2020, two weeks before the ICNIRP publication, the WHO Team on Public Health, Environmental and Social Determinants of Health issued a statement on $5 \mathrm{G}$ mobile networks and health: 'To date, and after much research performed, no adverse health effect has been causally linked with exposure to wireless technologies' (56). This statement is not correct based on current knowledge $(4,5,9-11,17,19)$ and was without a personal signature. The lack of research on $5 \mathrm{G}$ safety has been previously discussed (19). Furthermore, there is no evidence that can 'causally link' an adverse effect to an exposure. Causality is no empirical fact, it is an interpretation.

In the following section, only one (cancer) of the eight different end points in the ICNIRP publication (8) is discussed, since it deals with our main research area.

viii) Cancer.

'In summary, no effects of radiofrequency EMFs on the induction or development of cancer have been substantiated.

\section{Summary}

The only substantiated adverse health effects caused by exposure to radiofrequency EMFs are nerve stimulation, changes in the permeability of cell membranes, and effects due to temperature elevation. There is no evidence of adverse health effects at exposure levels below the restriction levels in the ICNIRP (1998) guidelines and no evidence of an interaction mechanism that would predict that adverse health effects could occur due to radiofrequency EMF exposure below those restriction levels'.

\section{Comments}

The ICNIRP draft (39) has been previously described to some extent (19). The published final version on health effects is virtually similar to the draft. It cannot be taken at face value as scientific evidence of no risk from RF radiation. One example is the following statement (p. 41): '...a set of case-control studies from the Hardell group in Sweden report significantly increased risks of both acoustic neuroma and malignant brain tumors already after less than five years since the start of mobile phone use, and at quite low levels of cumulative call time'.

This allegation is not correct according to our publication for glioma (11). In the shortest latency group $>1-5$ years, the risk of glioma was not increased (odds ratio (OR), 1.1; 95\% CI, 0.9-1.4) for use of wireless phones (mobile phone and/or cordless phone). There was a statistically significant increased risk of glioma per $100 \mathrm{~h}$ of cumulative use (OR, 1.011; 95\% CI, $1.008-1.014)$ and per year of latency (OR, 1.032; 95\% CI, 
1.019-1.046) (11). These published results are in contrast to the ICNIRP claims.

Regarding acoustic neuroma, the corresponding detailed results are reported in our previous study (57). The shortest latency period $>1-5$ years yielded an OR of 1.2 (95\% CI, 0.8-1.6) for use of wireless phones; the risk increased per 100 $\mathrm{h}$ of cumulative use (OR, 1.008; 95\% CI, 1.002-1.014) and per year of latency (OR, 1.056; 95\% CI, 1.029-1.085) (57). Therefore, the allegation by ICNIRP is false.

It is remarkable that ICNIRP is uninformed and that their writing is based on a misunderstanding of the peer-reviewed published articles as exemplified above. Additionally, our studies $(11,57)$ and another study by Coureau et al (58), as well as the IARC evaluation from $2011(1,2)$, are not included among the references. Several statements by ICNIRP are made without any scientific references. On the other hand, the Danish cohort study on mobile phone use (59) is included, in spite of the fact that it was judged by IARC $(1,2)$, as well as in our review (60), to be uninformative. A biased article written by authors including ICNIRP members, used to 'prove' the no-risk paradigm for RF radiation carcinogenesis (23), is cited by ICNIRP. Notably, the article has not undergone relevant peer-review and we believe that it should not have been published in its current version. The shortcomings in the aforementioned article are discussed in the following sections. As discussed below, another claim (23) is incorrect regarding increased risk of brain tumors associated with use of wireless phones: 'However, they are not consistent with trends in brain cancer incidence rates from a large number of countries or regions, which have not found any increase in the incidence since mobile phones were introduced'.

The criticism of the ICNIRP draft guidelines from 2018 by the EMF call (61) can also be applied to the current ICNIRP publication. The call has been signed by 164 scientists and medical doctors, as well as 95 NGOs: 'The International Commission on Non-Ionizing Radiation Protection (ICNIRP) issued draft Guidelines on 11th July 2018 for limiting exposure to electric, magnetic and electromagnetic fields $(100 \mathrm{kHz}$ to $300 \mathrm{GHz}) .1$ These guidelines are unscientific, obsolete and do not represent an objective evaluation of the available science on effects from this form of radiation. They ignore the vast amount of scientific findings that clearly and convincingly show harmful effects at intensities well below ICNIRP guidelines. 2 The guidelines are inadequate to protect humans and the environment. ICNIRP guidelines only protect against acute thermal effects from very short and intense exposure. The guidelines do not protect against harmful effects from low-intensity and longterm exposure, such as cancer, reproductive harm, or effects on the nervous system, although these effects are convincingly shown to appear from chronic exposure at intensities below ICNIRP limits.2,3

ICNIRP's mandate to issue exposure guidelines needs to be seriously questioned. ICNIRP is not independent of industry ties as it claims.12,13 Its opinions are not objective, not representative of the body of scientific evidence, but are biased in favor of industry. It is obvious from their reluctance to consider scientific findings of harm that ICNIRP protects industry, not the public health, nor the environment.
We ask the United Nations, the World Health Organization, and all governments to support the development and consideration of medical guidelines16, that are independent of conflict of interests in terms of direct or indirect ties to industry, that represent the state of medical science, and that are truly protective'.

In the recent report on ICNIRP published by two Members of the European Parliament it is concluded: 'That is the most important conclusion of this report: For really independent scientific advice we cannot rely on ICNIRP. The European Commission and national governments, from countries like Germany, should stop funding ICNIRP. It is high time that the European Commission creates a new, public and fully independent advisory council on non-ionizing radiation' (22).

\section{Other examples of scientific misrepresentation}

Published article. This section discusses an article with conclusions not substantiated by scientific evidence, representing a biased evaluation of cancer risks from mobile phone use and is an example of lack of objectivity and impartiality (23). The aforementioned report was used by ICNIRP 2020 (8) to validate that no risks have been found for brain and head tumors. Therefore, the article should be discussed in further detail.

The aforementioned article has numerous severe scientific deficiencies. One is that the results on use of cordless phones as a risk factor for brain tumors are not discussed. In fact, detailed results on cordless phones in studies by Hardell et al $(11,57)$ are omitted.

When discussing glioma risk, all results on cumulative use of mobile phones, as well as ipsilateral or contralateral use associated with tumor localization in the brain, are omitted from the figures in the main text. Some results in the article by Röösli et al (23), such as cumulative use, can be found in the Supplementary Material, although the increased risk among heavy users is disregarded $(11,57,58,62)$. In Supplementary Figure 4, all odds ratios regarding long-term ( $\geq 10$ years) use of mobile phones are above unity $(>1.0)$ for glioma and neuroma (23). No results are provided for ipsilateral mobile phone use (same side of tumor localization and mobile phone use), which is of large biological importance. Results on cumulative use, latency and ipsilateral use are especially important for risk assessment and have shown a consistent pattern of increased risk for brain and head tumors $(11,57)$.

In the aforementioned article, recall bias is discussed as the reason for increased risk (23). The studies by Hardell et al $(11,57)$ included all types of brain tumors. In one analysis, meningioma cases in the same study were used as the 'control' entity (11), and still a statistically significant increased risk of glioma was identified for mobile phone use (ipsilateral OR, 1.4; 95\% CI, 1.1-1.8; contralateral OR, 1.0; 95\% CI, 0.7-1.4) and for cordless phone use (ipsilateral OR, 1.4; 95\% CI, 1.1-1.9; contralateral OR, 1.1; 95\% CI, 0.8-1.6). If the results were 'explained' by recall bias, similar results would have been obtained for both glioma and meningioma. Thus, this type of analyses would not have yielded an increased glioma risk. Also, for acoustic neuroma a statistically significant increased risk was found using meningioma cases as 'controls' (57). Therefore, the results in the studies by Hardell et al $(11,57)$ cannot be explained by a systematic difference in assessment 
of exposure between cases and controls. These important methodological findings were disregarded by Röösli et al (23).

In the analyses of long-term use of mobile phones, a Danish cohort study on mobile phone use is included (59), which was concluded to be uninformative in the 2011 IARC evaluation $(1,2)$. A methodological shortcoming of the aforementioned study was that only private mobile phone subscribers in Denmark between 1982 and 1995 were included in the exposure group (59). The most exposed group, comprising 200,507 corporate users of mobile phones, were excluded and instead included in the unexposed control group consisting of the rest of the Danish population. Users with mobile phone subscription after 1995 were not included in the exposed group and were thus treated as unexposed at the time of cut-off of the follow up. No analysis of laterality of mobile phone use in relation to tumor localization was performed. Notably, this cohort study is now included in the risk calculations, although Martin Röösli was a member of the IARC evaluation group and should have been aware of the IARC decision. The numerous shortcomings in the Danish cohort study, discussed in detail in a peer-reviewed article (60), are omitted in the article by Röösli et al (23).

Regarding animal studies, a study by Falcioni et al (14) at the Ramazzini Institute on RF radiation carcinogenesis is only mentioned as a reference, but the results are not discussed. In fact, these findings (14) provide supportive evidence on the risk found in human epidemiology studies (3), as well as the results in the NTP study $(12,13)$.

Furthermore, for incidence studies on brain tumors, the results are not presented in an adequate way. There is a lot of emphasis on the Swedish Cancer Register data $(63,64)$, but the numerous shortcomings in the reporting of brain tumor cases to the register are not discussed. These shortcomings have been presented in detail in a previous study (63), but are disregarded by Röösli et al (23).

There is clear evidence from several countries regarding increasing numbers of patients with brain tumors, such as in Sweden $(63,64)$, England (65), Denmark (66) and France (67).

The article by Röösli et al (23), does not represent an objective scientific evaluation of brain and head tumor risk associated with the use of wireless phones, and should thus be disregarded. By omitting results of biological relevance and including studies that have been judged to be uninformative, the authors come to the conclusion that there are no risks: 'In summary, current evidence from all available studies including in vitro, in vivo, and epidemiological studies does not indicate an association between MP [mobile phone] use and tumors developing from the most exposed organs and tissues'.

Röösli et al (23), disregard the concordance of increased cancer risk in human epidemiology studies $(11,57,58,62)$ animal studies $(12-14,68,69)$ and laboratory studies $(15,16,37)$. It is unfortunate that the review process of the aforementioned article has not been of adequate quality. Finally, there is no statement in the article of specific funding of this particular work, which is not acceptable. Only a limited number of comments on general funding are provided. It is not plausible that there was no funding for the study. We believe that, due to its numerous limitations, the aforementioned article should not have been published.
CEFALO. In 2011, a case-control study on mobile phone use and brain tumor risk among children and adolescents termed CEFALO was published (70). The study appears to have been designed to misrepresent the true risk, since the following question regarding cordless phone use was asked: 'How often did [child] speak on the cordless phone in the first 3 years he/she used it regularly?'.

There are no scientific valid reasons to limit the investigation to the first 3 years. The result is a misrepresentation and a wrong exposure classification, since Aydin et al (70) willingly omitted any increase in the child's use of and exposure from cordless phone radiation after the first 3 years of use. This unscientific treatment of cordless phone exposure was not mentioned in the article other than in a footnote of a table and in the methods section (70); however, no explanation was provided: 'Specifically, we analyzed whether subjects ever used baby monitors near the head, ever used cordless phones, and the cumulative duration and number of calls with cordless phones in the first 3 years of use'.

Since previous studies have demonstrated that these phone types, in addition to mobile phones, increase brain tumor risk $(11,57)$, we believe that the exclusion of a complete exposure history on the use of cordless phones represents scientific misconduct.

In a critical comment the authors of the present study wrote: 'Further support of a true association was found in the results based on operator-recorded use for 62 cases and 101 controls, which for time since first subscription $>2.8$ years yielded OR 2.15 (95\% CI 1.07-4.29) with a statistically significant trend $(P=0.001)$. The results based on such records would be judged to be more objective than face-to-face interviews, as in the study that clearly disclosed to the interviewer who was a case or a control. The authors disregarded these results on the grounds that there was no significant trend for operator data for the other variables - cumulative duration of subscriptions, cumulative duration of calls and cumulative number of calls. However, the statistical power in all the latter groups was lower since data was missing for about half of the cases and controls with operator-recorded use, which could very well explain the difference in the results' (71).

Our conclusion was that: 'We consider that the data contain several indications of increased risk, despite low exposure, short latency period, and limitations in the study design, analyses and interpretation. The information certainly cannot be used as reassuring evidence against an association, for reasons that we discuss in this commentary' (71).

This is in contrast to the authors that claimed that the study was reassuring of no risk in a press release from Martin Röosli, July 28, 2011: 'Kein erhöhtes Hirntumorrisiko bei Kindern und Jugendlichen wegen Handys... Die Resultate sind beruhigend' ['No increased brain tumour risk in children and adolescents for mobile phone users... The results are reassuring'] (72).

A similar press release was issued by Maria Feychting at the Karolinska Institute in Stockholm stating: 'Reassuring results from first study on young mobile users and cancer risk... The so called CEFALO study does not show an increased brain tumor risk for young mobile users' (73). Considering the results and the numerous scientific shortcomings in the study (70), the statements in these press releases are not correct. 


\section{Discussion}

There is no doubt that several individuals included in Table I are influential, being members, as well as having consulting assignments, in several organizations, such as ICNIRP, BERENIS, the SSM, the Program Electromagnetic Fields and Health from ZonMw in the Netherlands, and the Rapid Response Group for the Japan EMF Information Center (74).

In fact, there appears to be a cartel of individuals working on this issue (75). Associate Professor Martin Röösli has had the chance to provide his view on the content of the present article relating to him. The only message from him was in an e-mail dated January 16, 2020: 'Just to be clear, all my research is funded by public money or not-for -profit fundations [foundations]. I think you will not help an important debate if you spread fake news'. Obviously, as described in the present article, his comment is not correct considering his funding from the telecom industry $(76,77)$.

As shown in Table I, few individuals, and mostly the same ones, are involved in different evaluations of health risks from $\mathrm{RF}$ radiation and will thus propagate the same views on the risks in agencies of different countries associated with the ICNIRP views $(4,5)$. Therefore, it is unlikely that they will change their opinions when participating in different organizations. Furthermore, their competence in natural sciences, such as medicine, is often low or non-existent due to a lack of education in these disciplines (2). Therefore, any chance for solid evaluations of medical issues is hampered. Additionally, it must be concluded that if the 'thermal only' dogma is dismissed, this will have wide consequences for the whole wireless community, including permissions for base stations, regulations of the wireless technology and marketing, plans to roll out $5 \mathrm{G}$, and it would therefore have a large impact on the industry. This may explain the resistance to acknowledge the risk by ICNIRP, EU, WHO, SSM and other agencies. However, the most important aspects to consider are human wellbeing and a healthy environment. Telecoms can make profit in a variety of ways, and wireless is just one of them. They have the capacity to maintain profits by using different techniques, such as optical fiber, that will provide more data with less RF radiation exposure. Particularly when considering the liability, they are incurring in their misguided insistence of wireless expansion that may ultimately catch up to them in the form of lawsuits, such as those previously experienced by asbestos and tobacco companies $(78,79)$.

A recent book describes how deception is used to capture agencies and hijack science (80). There are certain tools that can be used for this. One is to re-analyze existing data using methods that are biased towards predetermined results (23). For example, this can be performed by hiring 'independent experts' to question scientific results and create doubt $(81,82)$. As clearly discussed in a number of chapters of the books (80-82), front groups may be created to gain access to politicians and to influence the public with biased opinions. Other methods may involve intimidating and harassing independent scientists that report health risks based on sound science, or removing all funding from scientists who do not adhere to the no-risk proindustry paradigm. Another tool would be economic support and courting decision makers with special information sessions that mislead them on science and mask bribery $(3,5,19,80-82)$.
An industry with precise marketing goals has a big advantage over a loose scientific community with little funding. Furthermore, access to regulatory agencies and overwhelming them with comments on proposed regulations is crucial (3). To counteract all these actions is time consuming and not always successful (19). Nevertheless, it is important that these circumstances are explored and published in the peer-reviewed literature as historical notes for future use.

Based on the Swiss and ICNIRP experiences, some recommendations can be made. One is to include only unbiased and experienced experts without COIs for evaluation of health risks from $\mathrm{RF}$ radiation. All countries should declare a moratorium on $5 \mathrm{G}$ until independent research, performed by scientists without any ties to the industry, confirms its safety or not. $2 \mathrm{G}$, $3 \mathrm{G}, 4 \mathrm{G}$ and $\mathrm{WiFi}$ are also considered not to be safe, but $5 \mathrm{G}$ will be worse regarding harmful biological effects $(42,83,84)$. The authors of the present article recommend an educational campaign to educate the public about the health risks of RF radiation exposure, and safe use of the technology, such as the deployment of wired internet in schools (85), as previously recommended by the European Council resolution 1815 in 2011 (86) and The EMF Scientist Appeal (87). Additionally, it is recommended that the government takes steps to markedly decrease the current exposure of the public to RF radiation, $(88,89)$. Notably, DNA damage has been identified in peripheral blood lymphocytes using the comet assay technique, and in buccal cells using the micronucleus assay, in individuals exposed to RF radiation from base stations (90).

Finally, an alternative approach to the flawed ICNIRP safety standards may be the comprehensive work of the European Academy for Environmental Medicine (EUROPAEM) EMF working group that has resulted in safety recommendations, which are free from the ICNIRP shortcomings (50). Recently, the International Guidelines on Non-Ionising Radiation (IGNIR) have accepted EUROPAEM safety recommendations (91). The Bioinitiative group has recommended similar safety standards based on non-thermal EMF effects (92). WHO and all nations should adopt the EUROPAEM/Bioinitiative/IGNIR safety recommendations, supported by the majority of the scientific community, instead of the obsolete ICNIRP standards.

In conclusion, it is important that all experts evaluating scientific evidence and assessing health risks from RF radiation do not have COIs or bias. Being a member of ICNIRP and being funded by the industry directly, or through an industryfunded foundation, constitute clear COIs. Furthermore, it is recommended that the interpretation of results from studies on health effects of RF radiation should take sponsorship from the telecom or other industry into account. It is concluded that the ICNIRP has failed to conduct a comprehensive evaluation of health risks associated with $\mathrm{RF}$ radiation. The latest ICNIRP publication cannot be used for guidelines on this exposure.

\section{Acknowledgements}

The authors would like to thank Mr. Reza Ganjavi for valuable comments.

\section{Funding}

No funding was received. 


\section{Availability of data and materials}

Data sharing is not applicable to this article, as no datasets were generated or analyzed during the present study.

\section{Authors' contributions}

LH and MC contributed to the conception, design and writing of the manuscript. Both authors read and approved the final manuscript.

\section{Ethics approval and consent to participate}

Not applicable.

\section{Patient consent for publication}

Not applicable.

\section{Competing interests}

The authors declare that they have no competing interests.

\section{References}

1. Baan R, Grosse Y, Lauby-Secretan B, El Ghissassi F, Bouvard V, Benbrahim-Tallaa L, Guha N, Islami F, Galichet L and Straif K WHO International Agency for Research on Cancer Monograph Working Group: Carcinogenicity of radiofrequency electromagnetic fields. Lancet Oncol 12: 624-626, 2011.

2. IARC Monographs on the Evaluation of Carcinogenic Risks to Humans: Non-ionizing Radiation, Part 2: Radiofrequency Electromagnetic Fields. Vol. 102. IARC, Lyon, France, 2013.

3. Hardell L: Notes on parliament hearing in Tallinn, Estonia June 4, 2019 as regards the deployment of the fifth generation, 5G, of wireless communication. World Acad Sci J 1: 47-54, 2019.

4. Starkey SJ: Inaccurate official assessment of radiofrequency safety by the Advisory Group on Non-ionising Radiation. Rev Environ Health 31: 493-503, 2016.

5. Hardell L: World Health Organization, radiofrequency radiation and health - a hard nut to crack (Review). Int J Oncol 51: 405-413, 2017.

6. International Commission on Non-Ionizing Radiation Protection: Guidelines for limiting exposure to time-varying electric, magnetic, and electromagnetic fields (up to $300 \mathrm{GHz}$ ). Health Phys 74: 494-522, 1998.

7. International Commission on Non-Ionizing Radiation Protection: ICNIRP statement on the 'Guidelines for Limiting Exposure to Time-Varying Electric, Magnetic and Electromagnetic Fields (up to $300 \mathrm{GHz})^{\prime}$. Health Phys 97: 257-258, 2009.

8. International Commission on Non-Ionizing Radiation Protection (ICNIRP)1: Guidelines for Limiting Exposure to Electromagnetic Fields (100 kHz to $300 \mathrm{GHz})$. Health Phys 118: 483-524, 2020.

9. Belpomme D, Hardell L, Belyaev I, Burgio E and Carpenter DO: Thermal and non-thermal health effects of low intensity non-ionizing radiation: An international perspective. Environ Pollut 242 (Pt A): 643-658, 2018.

10. Miller AB, Morgan LL, Udasin I and Davis DL: Cancer epidemiology update, following the 2011 IARC evaluation of radiofrequency electromagnetic fields (Monograph 102). Environ Res 167: 673-683, 2018.

11. Hardell L and Carlberg M: Mobile phone and cordless phone use and the risk for glioma - Analysis of pooled case-control studies in Sweden, 1997-2003 and 2007-2009. Pathophysiology 22: 1-13, 2015.

12. National Toxicology Program: NTP technical report on the toxicology and carcinogenesis studies in $\mathrm{B} 6 \mathrm{C} 3 \mathrm{~F} 1 / \mathrm{N}$ mice exposed to whole-body radio frequency radiation at a frequency $(1,900 \mathrm{MHz})$ and modulations (GSM and CDMA) used by cell phones. NTP TR 596, March 26-28, 2018. https://ntp.niehs. nih.gov/ntp/about_ntp/trpanel/2018/march/tr596peerdraft.pdf. Accessed July 6, 2020.
13. National Toxicology Program: NTP technical report on the toxicology and carcinogenesis studies in Hsd:Sprague Dawley sd rats exposed to whole-body radio frequency radiation at a frequency $(900 \mathrm{MHz}$ ) and modulations (GSM and CDMA) used by cell phones. NTP TR 595, March 26-28, 2018. https://ntp. niehs.nih.gov/ntp/about_ntp/trpanel/2018/march/tr595peerdraft. pdf. Accessed July 6, 2020.

14. Falcioni L, Bua L, Tibaldi E, Lauriola M, De Angelis L, Gnudi F, Mandrioli D, Manservigi M, Manservisi F, Manzoli I, et al: Report of final results regarding brain and heart tumors in Sprague-Dawley rats exposed from prenatal life until natural death to mobile phone radiofrequency field representative of a $1.8 \mathrm{GHz}$ GSM base station environmental emission. Environ Res 165: 496-503, 2018.

15. Yakymenko I, Tsybulin O, Sidorik E, Henshel D, Kyrylenko O and Kyrylenko S: Oxidative mechanisms of biological activity of low-intensity radiofrequency radiation. Electromagn Biol Med 35: 186-202, 2016.

16. Smith-Roe SL, Wyde ME, Stout MD, Winters JW, Hobbs CA, Shepard KG, Green AS, Kissling GE, Shockley KR, Tice RR, et al: Evaluation of the genotoxicity of cell phone radiofrequency radiation in male and female rats and mice following subchronic exposure. Environ Mol Mutagen 61: 276-290, 2020.

17. Carlberg $M$ and Hardell L: Evaluation of mobile phone and cordless phone use and glioma risk using the Bradford Hill viewpoints from 1965 on association or causation. BioMed Res Int 2017: 9218486, 2017.

18. The 5G Appeal. http://www.5gappeal.eu/. Accessed July 6, 2020.

19. Hardell L and Nyberg R: Appeals that matter or not on a moratorium on the deployment of the fifth generation, $5 \mathrm{G}$, for microwave radiation. Mol Clin Oncol 12: 247-257, 2020. (Review).

20. Environmental Health Trust: Three-year moratorium on $4 \mathrm{G}$ and $5 \mathrm{G}$ in Geneva, Switzerland. https://ehtrust.org/three-year-moratorium-on-4g-5g-in-geneva-switzerland. Accessed July 6, 2020.

21. Flydal E: Head of Swiss Radiation Protection Committee accused of 5G-swindle. Nordic countries deceived, too. https:// einarflydal.com/wp-content/uploads/2020/02/Einar-Flydal-TheAccusations-against-R\%C3\%B6\%C3\%B6sli-and-the-BERENIS20200220_v-3.pdf. Accessed July 6, 2020.

22. Buchner $\overline{\mathrm{K}}$ and Rivasi $\mathrm{M}$ : The International Commission on Non-Ionizing Radiation Protection: Conflicts of interest, corporate capture and the push for $5 \mathrm{G}$. https://klaus-buchner. eu/wp-content/uploads/2020/06/ICNIRP-report-FINAL19-JUNE-2020.pdf. Accessed July 6, 2020.

23. Röösli M, Lagorio S, Schoemaker MJ, Schüz J and Feychting M: Brain and salivary gland tumors and mobile phone use: Evaluating the evidence from various epidemiological study designs. Annu Rev Public Health 40: 221-238, 2019.

24. Federal Office for the Environment: BERENIS - Swiss expert group on electromagnetic fields and non-ionising radiation. https://www.bafu.admin.ch/bafu/en/home/topics/electrosmog/ newsletter-of-the-swiss-expert-group-on-electromagnetic-fields -a/beratende-expertengruppe-nis-berenis.html. Accessed July 6 , 2020.

25. Office fédéral de l'environnement: Téléphonie mobile et 5G: le Conseilfédéraldécidedelasuitedelaprocedure.https://www.bafu. admin.ch/bafu/fr/home/themes/electrosmog/dossiers/rapportgroupe-de-travail-telephonie-mobile-et-rayonnement.html. Accessed July 6, 2020.

26. Département fédéral de l'environnement, des transports, de l'énergie et de la communication: Groupe de travail Téléphonie mobile et rayonnement: présentation d'un rapport factuel global. Bern, November 28, 2019. https://www.uvek.admin. $\mathrm{ch} / \mathrm{uvek} / \mathrm{fr} / \mathrm{home} / \mathrm{detec} / \mathrm{medias} /$ communiques-de-presse.msg-id77294.html. Accessed July 6, 2020.

27. Groupe de travail Téléphonie mobile et rayonnement: Rapport Téléphonie mobile et rayonnement. Publié par le groupe de travail Téléphonie mobile et rayonnement sur mandat du DETEC. November 18, 2019. https://ww w.newsd.admin. ch/newsd/message/attachments/59385.pdf. Accessed July 6, 2020.

28. Arbeitsgruppe Mobilfunk und Strahlung: Bericht Mobilfunk und Strahlung. Herausgegeben von der Arbeitsgruppe Mobilfunk und Strahlung im Auftrag des UVEK. November 18, 2019. https://www.newsd.admin.ch/newsd/message/attachments/59384. pdf. Accessed July 6, 2020.

29. Boeglin P: L'énigme $5 \mathrm{G}$ demeure. Un groupe de travail fédéral temporise sur les risques de santé et ne fixe pas de limite aux rayonnements. Le Courrier, November 29, 2019. https://lecourrier. ch/2019/11/29/lenigme-5g-demeure/. Accessed July 6, 2020. 
30. EMFscientist: International Appeal: Scientists call for Protection from Non-ionizing Electromagnetic Field Exposure. https://www. emfscientist.org/index.php/emf-scientist-appeal. Accessed July 6, 2020 .

31. Swiss Research Foundation for Electricity and Mobile Communication: Organisation. https://www.emf.ethz.ch/en/foundation/organisation/. Accessed July 6, 2020.

32. Swiss Research Foundation for Electricity and Mobile Communication: Publications. https://www.emf.ethz. $\mathrm{ch} / \mathrm{en} / \mathrm{promotion} /$ publications/?author $=664$. Accessed July 6, 2020

33. Swiss Research Foundation for Electricity and Mobile Communication: Annual Report 2017. https://www.emf.ethz. $\mathrm{ch} /$ fileadmin/redaktion/public/downloads/3 angebot/wissensvermittlung/jahresberichte/fsm-jb17_web_72dpi_red.pdf.Accessed July 6,2020 .

34. Swiss Research Foundation for Electricity and Mobile Communication: Sponsors and Supporters. https://www.emf ethz.ch/en/foundation/sponsors-supporters/?text=50\%25252525 $25252520 \mathrm{hz} \&$ author $=90 \& \mathrm{cHash}=6 \mathrm{acfa} 29405 \mathrm{f} 91 \mathrm{df} 1970 \mathrm{~b} 8 \mathrm{a} 8 \mathrm{e} 4 \mathrm{c}$ d2020e. Accessed July 6, 2020.

35. International Commission on Non-Ionizing Radiation Protection: Martin Röösli. Member. https://www.icnirp.org/en/about-icnirp/ commission/details/member-roosli.html. Accessed July 6, 2020.

36. International Commission on Non-Ionizing Radiation Protection (ICNIRP)1: ICNIRP Note: Critical evaluation of two radiofrequency electromagnetic field animal carcinogenicity studies published in 2018. Health Phys 118: 525-532, 2020.

37. Melnick RL: Commentary on the utility of the National Toxicology Program study on cell phone radiofrequency radiation data for assessing human health risks despite unfounded criticisms aimed at minimizing the findings of adverse health effects. Environ Res 168: 1-6, 2019.

38. Marques MM, Berrington de Gonzalez A, Beland FA, Browne P, Demers PA, Lachenmeier DW, Bahadori T, Barupal DK, Belpoggi F, Comba P, et al; IARC Monographs Priorities Group: Advisory Group recommendations on priorities for the IARC Monographs. Lancet Oncol 20: 763-764, 2019.

39. International Commission on Non-Ionizing Radiation Protection: Guidelines for limiting exposure to time-varying electric, magnetic and electromagnetic fields $(100 \mathrm{kHz}$ to $300 \mathrm{GHz})$. https://www.icnirp.org/cms/upload/consultation_upload/ICNIRP RF_Guidelines_PCD_2018_07_11.pdf. Accessed July 6, 2020.

40. International Commission on Non-Ionizing Radiation Protection: Commission. https://www.icnirp.org/en/abouticnirp/commission/index.html. Accessed July 6, 2020

41. IARC: IARC Monographs on the evaluation of carcinogenic risks to humans. https://monographs.iarc.fr/wpcontent/uploads/2018/06/mono102-F05.pdf. Accessed July 6, 2020

42. Neufeld E and Kuster N: Systematic derivation of safety limits for time-varying $5 \mathrm{G}$ radiofrequency exposure based on analytical models and thermal dose. Health Phys 115: 705-711, 2018.

43. Thielens A, Bell D, Mortimore DB, Greco MK, Martens L and Joseph W: Exposure of insects to radio-frequency electromagnetic fields from 2 to $120 \mathrm{GHz}$. Sci Rep 8: 3924, 2018.

44. Goodman EM, Greenebaum B and Marron MT: Effects of electromagnetic fields on molecules and cells. Int Rev Cytol 158 279-338, 1995.

45. Velizarov S, Raskmark $P$ and Kwee $S$ : The effects of radiofrequency fields on cell proliferation are non-thermal. Bioelectrochem Bioenerg 48: 177-180, 1999.

46. Panagopoulos DJ: Comparing DNA damage induced by mobile telephony and other types of man-made electromagnetic fields. Mutat Res 781: 53-62, 2019.

47. Panagopoulos DJ: Chromosome damage in human cells induced by UMTS mobile telephony radiation. Gen Physiol Biophys 38: 445-454, 2019.

48. Panagopoulos DJ, Karabarbounis A and Margaritis LH: Mechanism for action of electromagnetic fields on cells. Biochem Biophys Res Commun 298: 95-102, 2002.

49. Pall ML: Electromagnetic fields act via activation of voltagegated calcium channels to produce beneficial or adverse effects. J Cell Mol Med 17: 958-965, 2013.

50. Belyaev I, Dean A, Eger H, Hubmann G, Jandrisovits R, Kern M, Kundi M, Moshammer H, Lercher P, Müller K, et al: EUROPAEM EMF Guideline 2016 for the prevention, diagnosis and treatment of EMF-related health problems and illnesses. Rey Environ Health 31: 363-397, 2016.

51. Eliassen I and Pena P: Real 5G issues overshadowed by Covid-19 conspiracy theories. Investigate Europe. https://www.investigateeurope.eu/en/2020/5g-covid-conspiracy/. Accessed July 6, 2020.
52. ScientificCommittee onEmerging and NewlyIdentified HealthRisks (SCENIHR): Opinion on potential health effects of exposure to electromagnetic fields (EMF). European Commission.https://ec.europa. eu/health/scientific_committees/emerging/docs/scenihr_o_041.pdf. Accessed July 6, 2020

53. Sage C, Carpenter D and Hardell L: Comments on SCENIHR: Opinion on potential health effects of exposure to electromagnetic fields, Bioelectromagnetics 36:480-484 (2015). Bioelectromagnetics 37: 190-192, 2016.

54. World HealthOrganization: Radio frequency fields: Environmenta health criteria monograph consultation on the scientific review for the upcoming WHO environmental health criteria. https://web. archive.org/web/20141221142734/http://www.who.int/peh-emf/ research/rf_ehc_page/en/. Accessed July 6, 2020.

55. Microwave News: Will WHO kick its ICNIRP habit? Non-thermal effects hang in the balance. Repacholi's legacy of industry cronyism. https://microwavenews.com/news-center/canwho-kick-icnirp-habit. Accessed July 6, 2020.

56. World Health Organization: 5G mobile networks and health https://www.who.int/news-room/q-a-detail/5g-mobile-networksand-health. Accessed July 6, 2020.

57. Hardell L, Carlberg M, Söderqvist F and Mild KH: Pooled analysis of case-control studies on acoustic neuroma diagnosed 1997-2003 and 2007-2009 and use of mobile and cordless phones. Int J Oncol 43: 1036-1044, 2013.

58. Coureau G, Bouvier G, Lebailly P, Fabbro-Peray P, Gruber A, Leffondre K, Guillamo JS, Loiseau H, Mathoulin-Pélissier S, Salamon R, et al: Mobile phone use and brain tumours in the CERENAT case-control study. Occup Environ Med 71: 514-522, 2014.

59. Johansen C, Boice J Jr, McLaughlin J and Olsen J: Cellular telephones and cancer--a nationwide cohort study in Denmark. J Natl Cancer Inst 93: 203-207, 2001.

60. Söderqvist F, Carlberg M and Hardell L: Review of four publications on the Danish cohort study on mobile phone subscribers and risk of brain tumors. Rev Environ Health 27: 51-58, 2012

61. The EMF Call: Scientists and NGOs call for truly protective limits for exposure to electromagnetic fields $(100 \mathrm{kHz}$ to 300 GHz). https://www.emfcall.org/. Accessed July 6, 2020.

62. INTERPHONE Study Group: Brain tumour risk in relation to mobile telephone use: Results of the INTERPHONE international case-control study. Int J Epidemiol 39: 675-694, 2010.

63. Hardell L and Carlberg M: Increasing rates of brain tumours in the Swedish national inpatient register and the causes of death register. Int J Environ Res Public Health 12: 3793-3813, 2015.

64. Hardell L and Carlberg M: Mobile phones, cordless phones and rates of brain tumors in different age groups in the Swedish National Inpatient Register and the Swedish Cancer Register during 1998-2015. PLoS One 12: e0185461, 2017.

65. Philips A, Henshaw DL, Lamburn G and O'Carroll MJ: Brain tumours: Rise in glioblastoma multiforme incidence in England 1995-2015 suggests an adverse environmental or lifestyle factor. J Environ Public Health: doi.org/10.1155/2018/7910754.

66. Microwave News: Spike in 'aggressive' brain cancer in Denmark. https://microwavenews.com/short-takes-archive/spike-braincancer-denmark. Accessed July 6, 2020.

67. Phonegate Alert: Brain cancers: 4 times more new cases of glioblastoma in 2018 according to Public Health France. https:// www.phonegatealert.org/en/press-release-brain-cancers-4-timesmore-new-cases-of-glioblastoma-in-2018-according-to-public-healthfrance. Accessed July 6, 2020.

68. Tillmann T, Ernst H, Streckert J, Zhou Y, Taugner F, Hansen V and Dasenbrock C: Indication of cocarcinogenic potential of chronic UMTS-modulated radiofrequency exposure in an ethylnitrosourea mouse model. Int J Radiat Biol 86: 529-541, 2010

69. Lerchl A, Klose M, Grote K, Wilhelm AF, Spathmann O, Fiedler T, Streckert J, Hansen V and Clemens M: Tumor promotion by exposure to radiofrequency electromagnetic fields below exposure limits for humans. Biochem Biophys Res Commun 459: 585-590, 2015.

70. Aydin D, Feychting M, Schüz J, Tynes T, Andersen TV, Schmidt LS, Poulsen AH, Johansen C, Prochazka M, Lannering B, et al: Mobile phone use and brain tumors in children and adolescents: A multicenter case-control study. J Natl Cancer Inst 103: 1264-1276, 2011.

71. Söderqvist F, Carlberg M, Hansson Mild K and Hardell L: Childhood brain tumour risk and its association with wireless phones: A commentary. Environ Health 10: 106, 2011.

72. Universität Basel: Kein erhöhtes Hirntumorrisiko bei Kindern und Jugendlichen wegen Handys. https://www.unibas.ch/de/Aktuell/ News/Uni-Research/Kein-erh-htes-Hirntumorrisiko-bei-Kindernund-Jugendlichen-wegen-Handys.html. Accessed July 6, 2020. 
73. Karolinska Institutet: Reassuring results from first study on young mobile users and cancer risk. https://web.archive. org/web/20130203041836/https://ki.se/ki/jsp/polopoly.jsp?d=130 $\& a=125250 \& l=e n \& n e w s d e p=130$. Accessed July 6, 2020 .

74. Swedish Radiation Safety Authority: Declaration of disqualification, conflicts of interest and other ties for experts and specialists of the Swedish Radiation Safety Authority [Martin Röösli]. https://www. stralskyddsstiftelsen.se/wp-content/uploads/2020/03/martin_roosli_ coi_ssm.pdf. Accessed July 6, 2020.

75. Electromagnetic Radiation Safety: ICNIRP's Exposure Guidelines for Radio Frequency Fields. https://www.saferemr. com/search?q=cartel. Accessed July 6, 2020.

76. Swiss Research Foundation for Electricity and Mobile Communication: List of funded research projects. https://www. emf.ethz.ch/en/promotion/projects/list-of-funded-researchprojects/\# refno-16. Accessed July 6, 2020

77. Swiss Research Foundation for Electricity and Mobile Communication: Sponsors and Supporters. https://www.emf. ethz.ch/en/foundation/sponsors-supporters/?text=NmaF6u\%27A \%3D0\&author=horny. Accessed July 6, 2020.

78. Tweedale G: Secret ties in asbestos - downplaying and effacing the risks of a toxic mineral. In: Corporate Ties That Bind Walker MJ (ed). Skyhorse Publishing, New York, pp136-151, 2017.

79. Walhjalt B: Greenwashing: the Swedish experience. In: Corporate Ties That Bind. Walker MJ (ed). Skyhorse Publishing, New York, pp96-108, 2017.

80. Michaels D: The Triumph of Doubt: Dark Money and the Science of Deception. Oxford University Press, New York, 2020.

81. Michaels D: Doubt is Their Product. How Industry's Assault on Science Threatens Your Health. Oxford University Press, New York, 2008

82. Walker MJ: Corporate Ties that Bind. An Examination of Corporate Manipulation and Vested Interest in Public Health. Skyhorse Publishing, New York, 2017.

83. Di Ciaula A: Towards 5G communication systems: Are there health implications? Int J Hyg Environ Health 221: 367-375, 2018

84. Russell CL: $5 \mathrm{G}$ wireless telecommunications expansion: Public health and environmental implications. Environ Res 165: 484-495, 2018

85. Hedendahl LK, Carlberg M,Koppel T and Hardell L: Measurements of radiofrequency radiation with a body-borne exposimeter in Swedish schools with Wi-Fi. Front Public Health 5: 279, 2017.
86. Council of Europe: The potential dangers of electromagnetic fields and their effect on the environment. Resolution 1815, 2011. http://assembly.coe.int/nw/xml/XRef/Xref-XML2HTML-en.asp?fileid $=17994$. Accessed July 6, 2020.

87. EMFscientist: Welcome to EMFscientist.org. https://www. emfscientist.org/. Accessed July 6, 2020.

88. Koppel T, Ahonen M, Carlberg M, Hedendahl LK and Hardell L: Radiofrequency radiation from nearby mobile phone base stations-a case comparison of one low and one high exposure apartment. Oncol Lett 18: 5383-5391, 2019.

89. Hardell L, Carlberg M, Hedendahl LK, Koppel T and Ahonen M: Environmental radiofrequency radiation at the Järntorget Square in Stockholm Old Town, Sweden in May, 2018 compared with results on brain and heart tumour risks in rats exposed to $1.8 \mathrm{GHz}$ base station environmental emissions. World Acad Sci J 1: 47-54, 2019.

90. Gulati S, Yadav A, Kumar N, Kanupriya, Aggarwal NK, Kumar R and Gupta R: Effect of GSTM1 and GSTT1 polymorphisms on genetic damage in humans populations exposed to radiation from mobile towers. Arch Environ Contam Toxicol 70: 615-625, 2016.

91. International Guidelines on Non-Ionising Radiation: Guidelines IGNIR's latest independent guidelines on EMF exposure are available now to download and use. https://ignir.org/?page_id=8. Accessed July 6, 2020.

92. Bioinitiative: Bioinitiative 2012. A rationale for biologicallybased exposure standards for low-intensity electromagnetic radiation. https://bioinitiative.org/. Accessed July 6, 2020.

93. Swedish Radiation Safety Authority: Publications. https://www. stralsakerhetsmyndigheten.se/en/publications/?area=Magnetf\% c3\%a4lt+och+tr\%c3\%a5dl\%c3\%b6s+teknik. Accessed July 6 , 2020.

94. International Commission on Non-Ionizing Radiation Protection: Structure and Membership. https://www.icnirp.org/en/abouticnirp/structure-membership/index.html. Accessed July 6, 2020.

95. International Telecommunication Union: van DEVENTER Tahera Emilie. https://www.itu.int/en/ITU-T/Workshops-andSeminars/emf/201307/Pages/vanDEVENTERTaheraEmilie.aspx. Accessed July 6, 2020.

This work is licensed under a Creative Commons Attribution-NonCommercial-NoDerivatives 4.0 International (CC BY-NC-ND 4.0) License. 